\title{
23. MAGNETOSTRATIGRAPHY OF LEG 73 SEDIMENTS 1
}

\author{
Lisa Tauxe ${ }^{2}$, Lamont-Doherty Geological Observatory, Columbia University, Palisades, N.Y. \\ Peter Tucker, Warren Spring Laboratory, Stevenage, Hertfordshire SG1 2BX, United Kingdom \\ Nikolai P. Petersen, Institut für Geophysik, University of Munich, D-8000 Munich, Federal Republic of Germany \\ and \\ John L. LaBrecque, Lamont-Doherty Geological Observatory, Columbia University, Palisades, N.Y.
}

\begin{abstract}
This chapter presents the magnetostratigraphy of Leg 73 sediments. We correlate the magnetostratigraphy to the geomagnetic reversal time scale (GRTS), providing tight age-depth control for the five sites analyzed. The sediment accumulation rates implied by the magnetostratigraphy are calculated.

The data presented here represent a remarkable record of the fine-scale polarity history of the Earth's magnetic field. These data place constraints on the interpretation of small-scale marine magnetic anomalies, which are modeled equally effectively by field intensity fluctuations and by polarity reversals. At least some of the "tiny wiggles" correspond to very short polarity units in the magnetostratigraphic record.

Combining the age and average inclination information available from the magnetostratigraphy, we present paleolatitudes versus time for the Leg 73 drill sites.
\end{abstract}

\section{INTRODUCTION}

Before the advent of the hydraulic piston corer, (HPC), knowledge of the magnetostratigraphy of deep sea sediments was limited by the maximum depth of penetration of traditional piston coring systems to the uppermost 25 or $30 \mathrm{~m}$ of sediment. However, analyses of these piston cores demonstrated the value of magnetostratigraphy for the absolute temporal correlation of the biostratigraphic, paleoceanographic, and paleoclimatic information contained in the cores (e.g., Opdyke et al., 1974; Hays et al., 1969; Theyer and Hammond, 1974). Although mainly limited to working with Neogene sediments, various workers have attempted to use DSDP cores to establish magnetostratigraphic-biostratigraphic correlations for the Paleogene (Hailwood et al., 1979; Sclater et al., 1974). These correlations rely largely on information from the bottoms of the holes and assume that there is no hiatus between the formation of the ocean floor and the onset of sedimentation. Hardenbol and Berggren (1978) proposed a correlation between the geomagnetic reversal time scale (GRTS) and the biostratigraphic time scale by assuming that the absolute ages assigned to the two systems were equally well determined.

The sediments recovered during Leg 73 permitted the direct correlation of the biostratigraphic and magnetostratigraphic time scales in deep sea sediment cores to be extended into the Paleogene, complementing recent work on marine sections exposed in Umbria (Lowrie et al., 1982). This paper presents the magnetostratigraphic results from Leg 73.

\footnotetext{
${ }^{1}$ Hsü, K. J., LaBrecque, J. L., et al., Init. Repts. DSDP, 73: Washington (U.S. Govt. Printing Office).

2 Present address: Scripps Institution of Oceanography, La Jolla, Calif. 92093.
}

\section{MAGNETOSTRATIGRAPHIC NOMENCLATURE FOR THE PALEOGENE AND MESOZOIC}

The first magnetic time scale was divided into epochs (Cox et al., 1963), which were later named Brunhes, Matuyama, and Gauss (Cox et al., 1964). Hays and Opdyke (1967) extended the epoch system, defining new time units based on the magnetostratigraphy of deep sea sediment cores. The epochs were correlated with the pattern of magnetic anomalies (Heirtzler et al., 1968) to construct a magnetic polarity time scale (Hays and Opdyke, 1967; Ryan et al., 1974).

Because the term epoch has a different connotation in stratigraphy, the subcommission on stratigraphic nomenclature recently recommended new terminology for the magnetic polarity time scale in which the magnetic time units hitherto known as epochs would be referred to as chrons (Hedberg et al., 1979).

Until now, no formal magnetic time units (chrons) have been defined for pre-Neogene times. Magnetostratigraphic patterns in the Mesozoic and Paleogene have been correlated with the numbered magnetic anomalies, which are not time units (see for example Alvarez et al., 1977). We find such schemes as that employed by Butler and Coney (1981) (i.e., Anomaly 13 Chron) cumbersome, and simply referring to the time between the formation of Anomalies 13 and 15 as Chron 13 leads to confusion with the pre-existing chron nomenclature for the Neogene. We therefore propose to define pre-Neogene chrons by a scheme that incorporates the numbering system of the magnetic anomaly pattern but distinguishes the time unit (chron) from the geomagnetic anomaly by prefixing the anomaly number by the letter C. Our convention defines a Paleogene magnetic chron as the interval between the youngest reversal boundaries of the numbered magnetic anomalies; the magnetic 
anomalies are those defined by Heirtzler et al. (1968) and refined by LaBrecque et al. (1977). The Cenozoic and latest Mesozoic anomaly numbers are associated with the predominantly normal portions of the chron. The chrons may be divided into subchrons by the addition of an $\mathbf{N}$ or $\mathbf{R}$ suffix, which refers to the predominantly normal or reversed segment of a chron. Therefore, the crust beneath Magnetic Anomaly 10 was created during Magnetic Subchron C-10-N.

\section{METHODS}

At first it was hoped that a Digico long core spinner magnetometer could be used to establish the magnetic polarity stratigraphy of the sediments, because it is faster and requires less sampling of the core than discrete sampling. However, pervasive rust contamination, the lack of relative declination control, and the inability to remove any secondary overprinting, together with the scientists' reluctance to risk destroying the fine structure in the poorly indurated sediments, made the technique impractical for Leg 73. For these reasons, oriented 6- to $7-\mathrm{cc}$ specimens were taken at intervals ranging from every $10 \mathrm{~cm}$ to every $40 \mathrm{~cm}$, depending on sediment type.

Distributed pilot specimens were subjected to progressive alternating field (A.F.) demagnetization. The Zijderveld diagrams presented in Figure 1 illustrate the range of behavior typical of the recov-
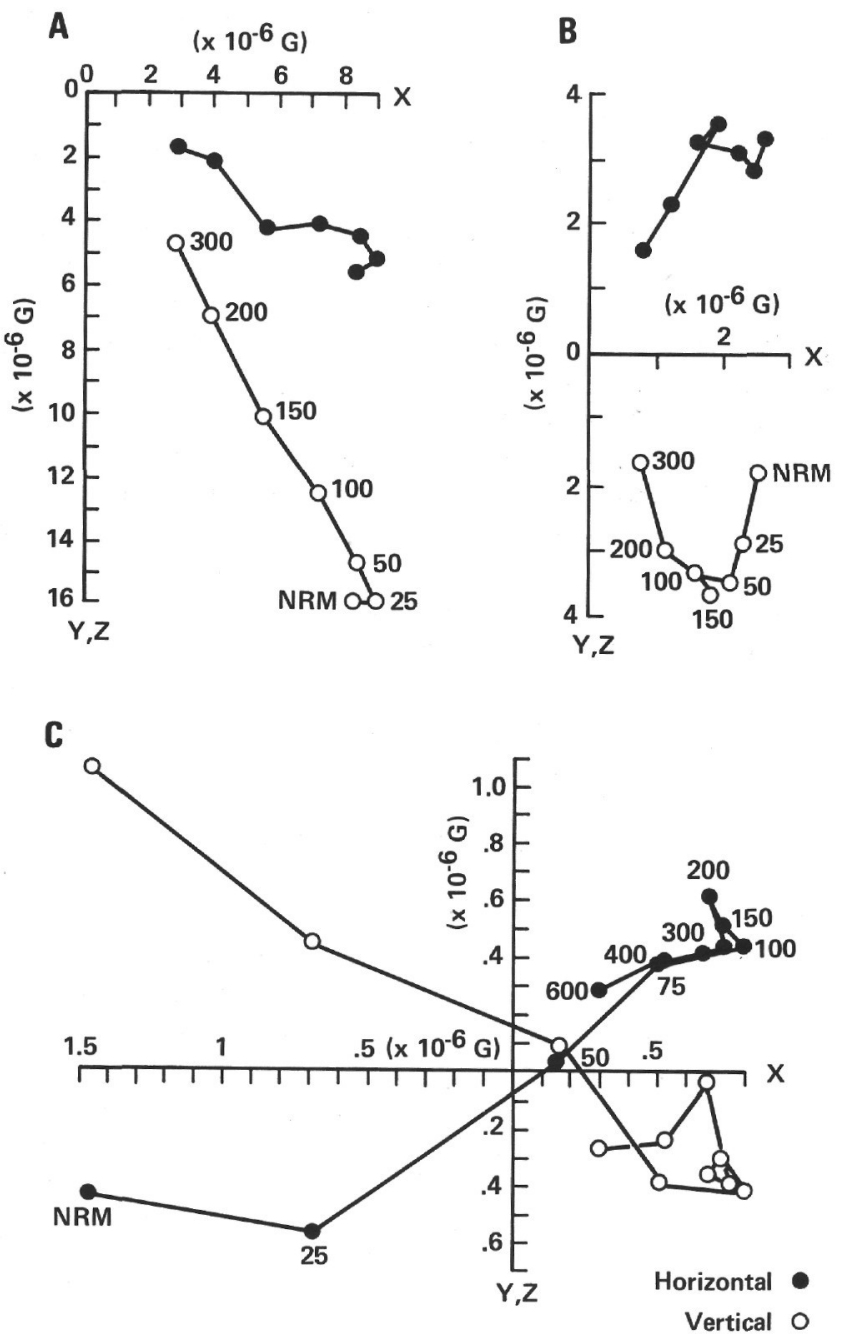

Figure 1. Vector demagnetization plots of the range of behavior in Leg 73 sediments. Units are peak alternating fields in oersteds. A. Type I behavior. B. Type II behavior. C. Type III behavior. ered sediments; such plots also formed the basis for the classification of the Leg 73 sediments. Specimens that exhibited no secondary overprinting upon A.F. demagnetization (straight line decay to the origin in both the vertical and horizontal projections of the remanence vector) were designated Type I (Fig. 1A). Type II sediments were partially overprinted but had polarities that were not obscured (Fig. 1B). Sediments in which the original polarity was completely masked by a relatively soft secondary (normal) overprint that could be removed by A.F. demagnetization were classified Type III (Fig. 1C), and sediments in which the overprinting was complete and could not be removed by A.F. demagnetization were classified Type IV. Sediments of Types I and II are potentially suitable for the long core spinner; however, most of the Miocene sediments were classified Type III or IV and had to be demagnetized by either alternating field or thermal means.

All specimens were subjected to A.F. demagnetization on board ship. Thermal demagnetization equipment was not available on the Glomar Challenger, so Type IV specimens could not be properly treated.

Since all the sites are in the midlatitudes, the inclination of a demagnetized specimen can be used as an indication of polarity. In the Southern Hemisphere, negative inclinations result from a normal field, positive inclinations from a reversed field. In this chapter we present plots of demagnetized specimen inclinations versus depth for Sites 519 and 521 through 524; Figure 2 (Site 519) is representative. The interpretations of polarity are shown at the right, black being normal and white reversed. Wherever possible, polarity units represented by single specimens were resampled in order to verify the results. In some cases, resampling failed to confirm the existence of a unit. Several explanations are possible: the polarity unit may be very short (and may or may not be included in the GRTS); the sediment may have been disturbed during the coring process or may have failed to act as an accurate recorder of the Earth's magnetic field; or the specimen may have been inverted during sampling. Because polarity units represented by single specimens may be spurious, they are indicated by arrows in the figures and are considered tentative.

NRM intensities have been plotted in log gauss to the left of the inclinations. The noise level of the shipboard magnetometer was measured as being on the order of $10^{-8} \mathrm{G}$, and all the remanent intensities were above $10^{-7} \mathrm{G}$ (most were from $10^{-6}$ to $10^{-5} \mathrm{G}$ ). In other words, in no case was a specimen too weakly magnetized to be easily measured on the shipboard magnetometer.

Biostratigraphic ages and lithologies are indicated to the left. These units are based on analyses presented elsewhere in the Initial Reports.

\section{RESULTS}

\section{Site 519}

\section{Magnetostratigraphy}

The paleomagnetic results from the sediments of Site 519 are presented in Figure 2. The specimens taken from the upper $80 \mathrm{~m}$ of the section were all Type I or Type II. Between $80 \mathrm{~m}$ (middle Pliocene) and about $145 \mathrm{~m}$ subbottom the specimens tended to be Type III (A.F. demagnetization was necessary to determine specimen polarity). In the ridge crest facies, the specimens exhibited Type I or II behavior. All sediment specimens at Site 519 were subjected to A.F. demagnetization at peak fields of at least 100 Oe. Average positive (normal) specimen inclinations tended to be steeper than the average negative (reversed) specimen inclinations at this site, suggesting the presence of a persistent overprint in the present field that is steeper than the expected dipole field for the site. In spite of this we feel that the polarity of the specimens has been adequately determined throughout the section. Our preferred correlation to the time scale is shown by dashed lines. The time scale is that of LaBrecque et al. (1977) as recalculated by Mankinen and Dalrymple (1979). The age, position, and 


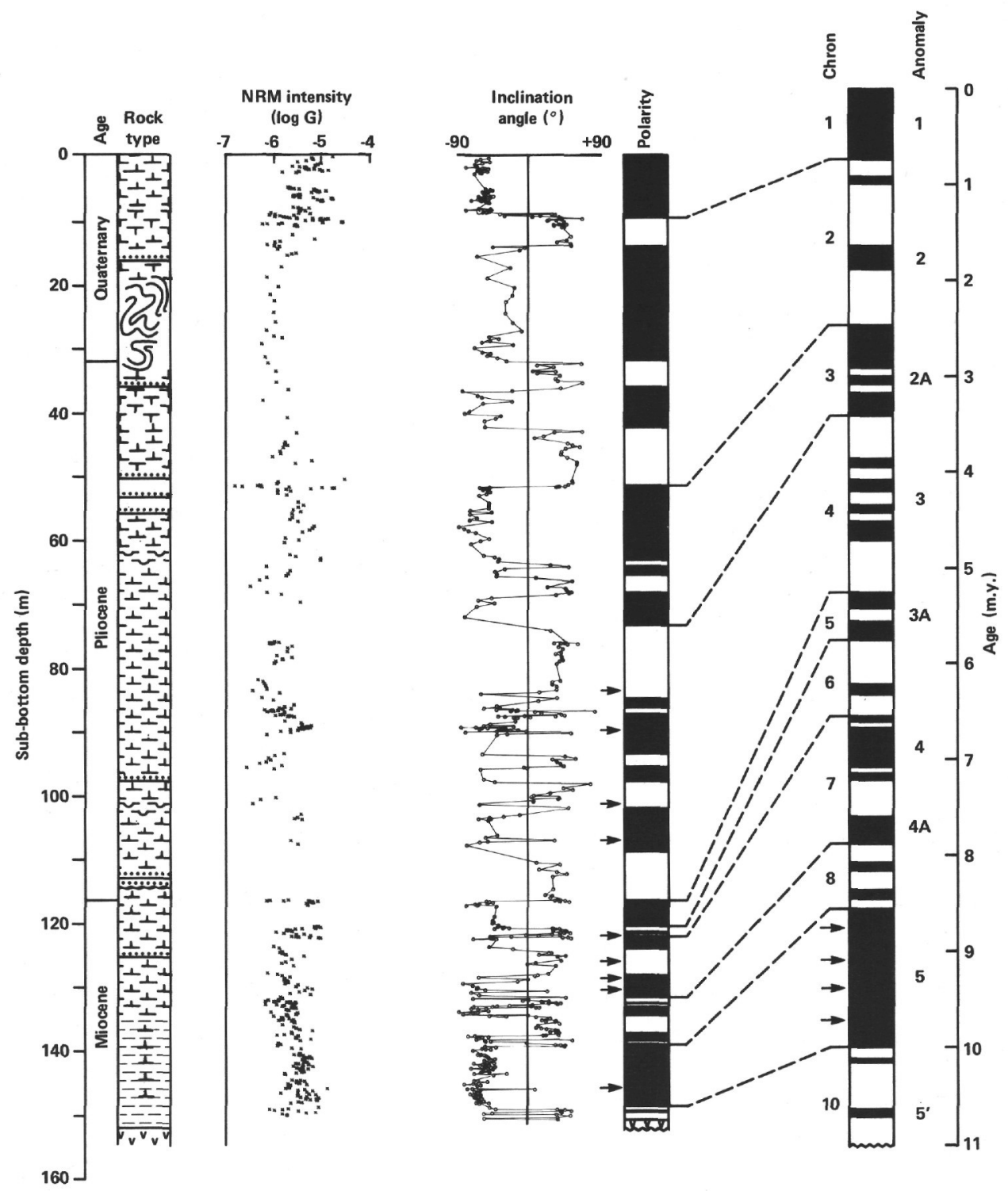

Figure 2. The magnetostratigraphy of Site 519. Data are demagnetized specimen inclinations. Dashed lines indicate the preferred correlation to the time scale of LaBrecque et al. (1977) as recalculated by Mankinen and Dalrymple (1979). Polarity log is based on inclinations, black being normal (negative) and white being reversed (positive). Arrows to the left of the polarity log show the positions of polarity units that are defined by single samples and are therefore tentative. Arrows to the left of the time scale are "tiny wiggles" identified by LaBrecque et al. (1977).

depth of important reversal boundaries are listed for this and the other sites in Table 1. The magnetic unit we correlated to the Jaramillo subchron (the youngest normal subchron in Chron 2) appears to be much too thick when compared to the GRTS. This magnetic unit occurs in slumped sediments. Samples taken from the slump are consistently normally magnetized with shallow inclinations and tend to be more weakly magnetized than elsewhere. Since remagnetization in the present field (Brunhes chron) tends to produce steeply and more strongly magnetized remanent magnetizations, we believe that the sediments, which are of mixed stratigraphic age, were remagnetized by the extensive slumping that occurred during the Jaramillo subchron.

The correlation of our section to the GRTS from Chron 5 to Chron 8 is based on knowledge of the car- bonate content of the sediment and hence an estimate of the probable sediment accumulation rate. Chron 6 appears to be far too thin stratigraphically if sediment accumulation rate is assumed to be constant; however, it occurs in a carbonate content minimum caused by extensive dissolution, so the assignment is believed to be justified. Our correlation of Chrons 8 and 9 to the GRTS seems to indicate the presence of several subchrons that are not represented in the time scale. The "extra" subchron in Chron 8 has also been documented in the Siwaliks of Northern Pakistan (Tauxe and Opdyke, 1982; Tauxe, 1979). The reversed magnetic unit indicated by an arrow in the interval correlated to Chron 9 suggests the existence of a reversed subchron within Chron 9. Reversed subchrons have been documented within Chron 9 in Iceland (McDougall et al., 
Table 1. Age and position of important reversal boundaries.

\begin{tabular}{lccc}
\hline Reversal boundary & $\begin{array}{c}\text { Age } \\
\text { (m.y.) }\end{array}$ & $\begin{array}{c}\text { Core-Section- } \\
\mathrm{cm}\end{array}$ & $\begin{array}{c}\text { Sub-bottom } \\
\text { depth (m) }\end{array}$ \\
\hline Site 519 & & & \\
& & & \\
Brunhes/Matuyama & 0.72 & $3-2-14 / 3-2-22$ & $8.94 / 9.02$ \\
Jaramillo, top & 0.91 & $4-2-109 / 4-2-121$ & $13.89 / 14.11$ \\
Jaramillo, bottom & 0.98 & $9-1-33 / 9-1-71$ & $31.63 / 32.01$ \\
Olduvai, top & 1.66 & $10-1-53 / 10-1-91$ & $35.83 / 36.21$ \\
Olduvai, bottom & 1.88 & $11-2-80 / 11-2-143$ & $42.00 / 42.63$ \\
Matuyama/Gauss & 2.47 & $13-2-138 / 13-2-142$ & $51.38 / 51.42$ \\
Kaena, top & 2.92 & $16-1-21 / 16-2-31$ & $61.91 / 63.51$ \\
Mammoth, top & 3.08 & $16-3-61 / 16 / 3 / 83$ & $65.31 / 65.53$ \\
Gauss/Gilbert & 3.41 & $18-1-114 / 18-3-30$ & $71.64 / 73.80$ \\
Cochiti, top & 3.86 & $21-1-101 / 21-2-31$ & $84.71 / 85.51$ \\
Nunivak, top & 4.08 & $21-3-45 / 21-3-49$ & $87.15 / 87.19$ \\
C1, top & 4.35 & $23-2-138 / 23-3-9$ & $95.38 / 95.59$ \\
C2, top & 4.52 & $25-1-66 / 25-2-22$ & $101.96 / 103.02$ \\
Gilbert/Chron 5 & 5.26 & $28-2-55 / 28-2-57$ & $116.55 / 116.57$ \\
Chron 5/Chron 6 & 5.77 & $29-2-36 / 29-2-41$ & $120.36 / 120.41$ \\
Chron 6/Chron 7 & 6.54 & $29-3-34 / 29-3-42$ & $121.84 / 121.92$ \\
Chron 7/Chron 8 & 7.88 & $32-1-77 / 32-1-91$ & $132.07 / 132.21$ \\
Chron 8/Chron 9 & 8.56 & $33-3-51 / 33-3-56$ & $139.21 / 139.26$ \\
Chron 9/Chron 10 & 10.00 & $36-1-60 / 36-1-65$ & $149.10 / 149.15$ \\
& & &
\end{tabular}

Site 521

$\begin{array}{lr}\text { Brunhes/Matuyama } & 0.72 \\ \text { Jaramillo, top } & 0.91 \\ \text { Jaramillo, bottom } & 0.98 \\ \text { Olduvai, top } & 1.66 \\ \text { Olduvai, bottom } & 1.88 \\ \text { Matuyama/Gauss } & 2.47 \\ \text { Mammoth, top } & 3.88 \\ \text { Gauss/Gilbert } & 3.41 \\ \text { Chron 15, middle } & 14.70 \\ \text { Chron 15/Chron 16 } & 15.12 \\ \text { Chron 16, middle } & 16.14\end{array}$

Site 522

Brunhes/Matuyama

Olduvai, top

Olduvai, bottom

Matuyama/Gauss

Gauss/Gilbert

$\mathrm{C}-6 \mathrm{~B}$, top

C-6C-N1, top

C-6C-N2, top

C-6C-N3, top

$\mathrm{C}-6 \mathrm{C} / \mathrm{C}-7$

C-7/C-7A

C-7A/C-8

C-8/C-9

C-9/C-10

C-10/C-11

$\mathrm{C}-11 / \mathrm{C}-12$

C-12/C-13

C-13-N2/C-13-R2

$\mathrm{C}-13 / \mathrm{C}-15$

C-15/C-16

Site 523

$\begin{array}{ll}\text { C-12-N/C-12-R } & 33.68 \\ \text { C-12/C-13 } & 36.18 \\ \text { C-16/C-17 } & 40.63 \\ \text { C-17/C-18 } & 42.48 \\ \text { C-18/C-19 } & 44.50 \\ \text { C-19/C-20 } & 46.01 \\ \text { C-20/C-20-R } & 47.60\end{array}$

Site 524

$\begin{array}{ll}\text { C-24/C-25 } & 60.17 \\ \text { C-26/C-27 } & 63.89 \\ \text { C-27/C-28 } & 64.96 \\ \text { C-28/C-29 } & 65.98 \\ \text { C-29/C-30 } & 67.04 \\ \text { C-30/C-31 } & 68.54 \\ \text { C-31-N/C-31-R } & 69.29\end{array}$

1976) as well as in Pakistan (Barndt et al., 1978; Tauxe and Opdyke, 1982). The arrows to the left of the time scale indicate correlated linear magnetic anomalies that can be modelled equally well as short subchrons (Blakely, 1974) or as fluctuations in intensity (Cande and LaBrecque, 1974). We feel that at least some of the "tiny wiggles" in the magnetic anomaly pattern could be caused by short-term reversals of the magnetic field.

Site 519 was drilled on Anomaly $5^{\prime}$. Therefore the age of the oldest sediment (Chron 10) is the same as the age of the magnetization of the basement. The results from Site 519 suggest that the onset of sedimentation is penecontemporaneous with the formation of basement at this site.

\section{Sediment Accumulation Rates}

If the correlation to the GRTS shown in Figure 2 is at least approximately correct, sediment accumulation versus time can be determined for Site 519. The sediment accumulation curve shown in Figure 3 reflects the paleoceanographic history of Site 519. The sedimentation that takes place through the Brunhes to the top of the Jaramillo is typical pelagic sedimentation (nannofossil ooze) and occurs at an average rate of $15.4 \mathrm{~m} / \mathrm{m}$.y. As previously noted, a slump during the Jaramillo radically increased the sediment accumulation rate, causing a kink in the curve between about 15 and $30 \mathrm{~m}$ sub-bottom. From the top of the Olduvai (1.66 m.y.) to the top of Chron 5 (5.26 m.y.), the sediment accumulation rate is fairly constant at $22.4 \mathrm{~m} / \mathrm{m}$.y. The "Messinian crisis," which is characterized by a rise in the calcite compensation depth (CCD), resulted in extensive but variable dissolution during the upper Miocene. This event is clearly marked by a sharp decrease in the sediment accumulation rate at about $120 \mathrm{~m}$ sub-bottom. The lower

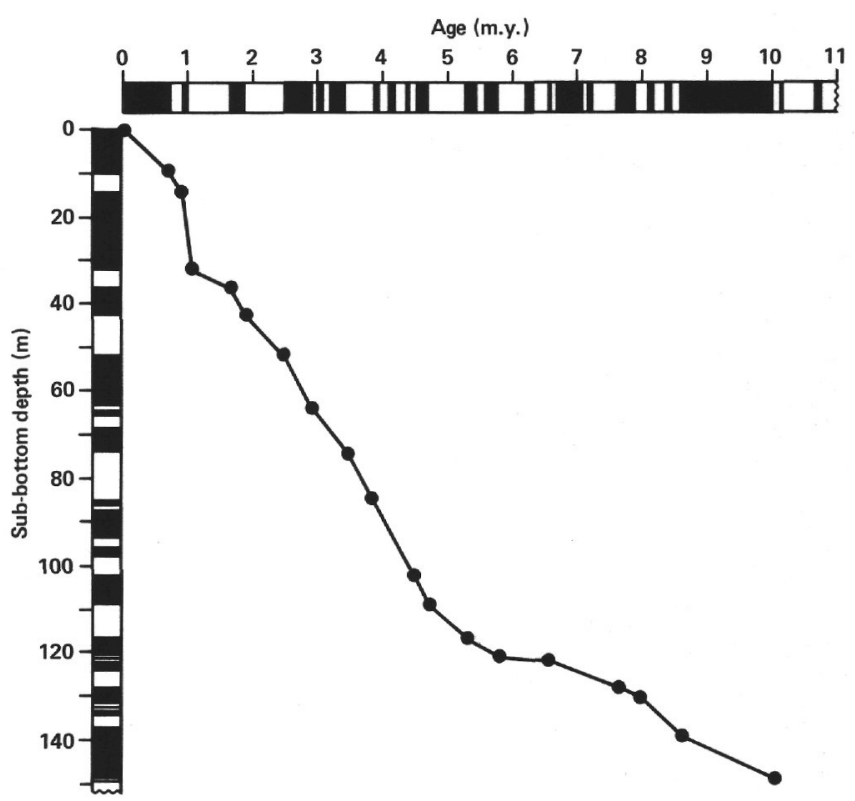

Figure 3. Sediment accumulation versus age for Site 519. Figure is based on Fig. 2. 
sediment accumulation rate is accompanied by a change from Type II (Fig. 1B) to Type III (Fig. 1C) behavior that is caused by an increase in the ability of the sediment to acquire a viscous remanent magnetization (VRM). The sediment accumulates slower, so it is exposed to corrosive bottom waters longer, and magnetite is altered into some other iron-oxide phase, perhaps the hydrated iron oxide of the red pigment. Since the smallest grains (which are the most stable magnetically) would be attacked first, dissolution might cause an increase in the proportion of the remanence being carried by the larger magnetite grains, effectively decreasing the stability of the remanence. (See the chapter in this volume by Tucker and Tauxe for a more complete discussion.)

The sediments at the bottom of the sediment column at Site 519 were deposited on the ridge crest, and they are characterized by Type I or Type II magnetic behavior. The mineralogical changes that take place in ridge crest facies are not well understood, but they seem to result in a high level of magnetic stability.
Site 521

\section{Magnetostratigraphy}

The results from Site 521 are presented in Figures 4 and 5. Specimens above $30 \mathrm{~m}$ sub-bottom were subjected to A.F. demagnetization in peak alternating fields of 100 to 150 Oe. All specimens from sub-bottom depths $>30 \mathrm{~m}$ were treated at $200 \mathrm{Oe}$. One possible correlation to the time scale is shown by the dashed lines in Figure 4 . The depths and ages of the identifiable reversal boundaries are listed in Table 1 . Above about $40 \mathrm{~m}$ sub-bottom, specimens are classified as Type I or Type II, and the Brunhes (Chron 1) through the upper part of the Gilbert (Chron 4) can be identified fairly easily. The reversed subchron within the magnetic unit that we have correlated to the Brunhes may be the Blake subchron. Between about 40 and $70 \mathrm{~m}$, sub-bottom, the specimens tended to be Type III or Type IV. Many of these were removed from the plastic sample boxes, wrapped in aluminum foil, and treated to thermal demagnetization at

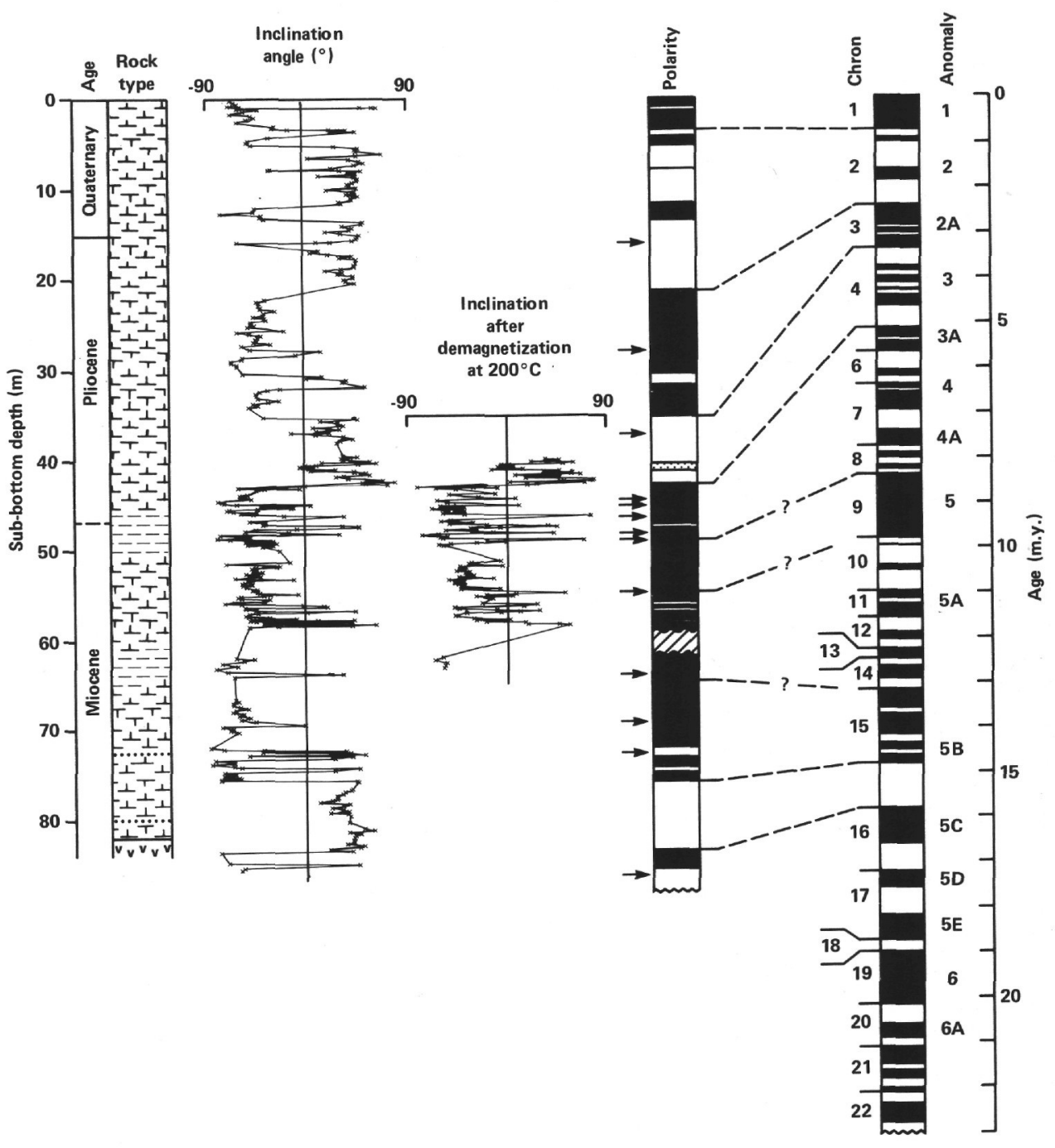

Figure 4. The magnetostratigraphy of Site 521 (see caption for Fig. 2). 


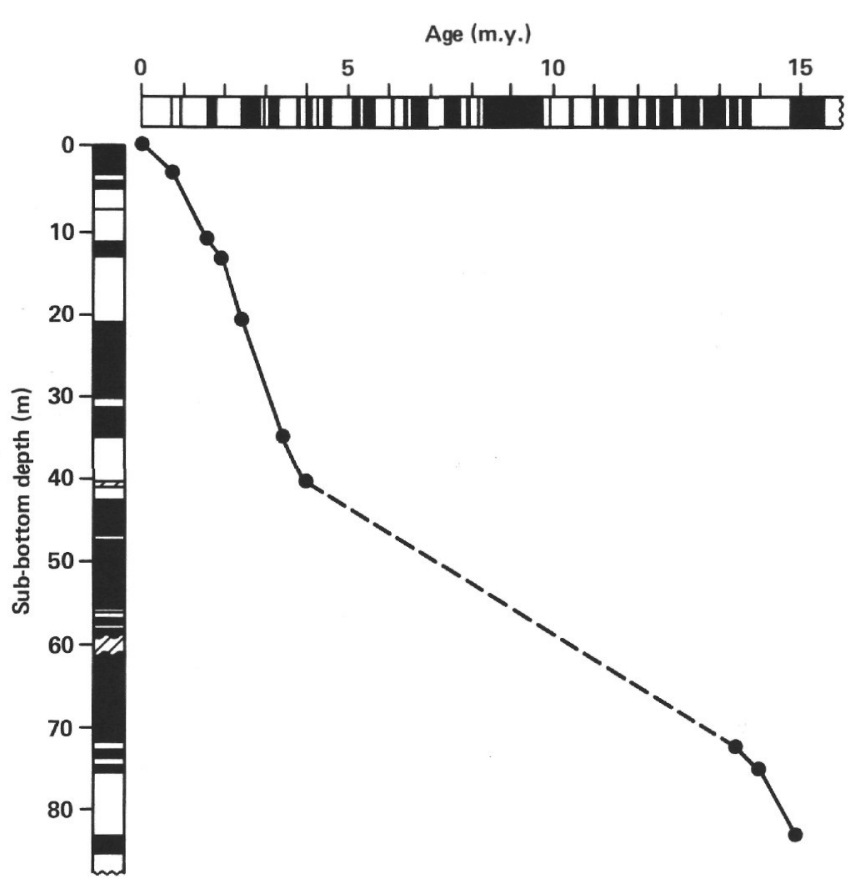

Figure 5. Sediment accumulation versus age at Site 521. Dashed line signifies that correlation is uncertain.

$200^{\circ} \mathrm{C}$ in an attempt to demagnetize a possible goethite overprint. The results of the thermal treatment are presented to the right, and, although some specimens became reversed, the magnetostratigraphic pattern remains uninterpretable. This part of the section was sampled at $10-\mathrm{cm}$ intervals. It is apparent that a higher sampling density is needed to provide higher resolution in the magnetic stratigraphy. Below about $70 \mathrm{~m}$ sub-bottom in the ridge crest facies, the magnetic stratigraphy is once again interpretable. The site was drilled on Anomaly $5 \mathrm{C}$, hence the correlation to Chron 16 at the base. The double normal characteristic of Anomaly 5B (bottom of Chron 15) is clearly discernible in the polarity log of Site 521. Above the middle of Chron 15, however, the combined effects of poor recovery, inadequate sampling density, and a hard magnetic overprint make it difficult to interpret the magnetostratigraphy.

\section{Sediment Accumulation Rates}

Figure 5 shows a plot of sediment accumulation versus time. The slow decrease in rate with decreasing subbottom depth during the Pliocene is probably the result of ridge crest subsidence, which causes a slight increase in dissolution in more recent times. The uncertainties in the magnetostratigraphy do not permit the details of the fluctuations in the sediment accumulation rates during the "Messinian crisis" ending in the middle Gilbert to be determined; however, a broad tendency toward a slower rate can be observed.

\section{Site $\mathbf{5 2 2}$}

The results from Site 522 (Holes 522 and 522A) are presented in Figures 6, 7, and 8. The data in the column labeled A in Figure 6 are the analyses from Hole 522A. It is possible to identify the Brunhes, Matuyama, Gauss, and upper Gilbert chrons in the upper $25 \mathrm{~m}$ of the section (Fig. 7). Specimens in this interval were demagnetized in peak A.F. fields of 150 Oe. The section from about 25 to $50 \mathrm{~m}$ sub-bottom is very compressed, and although the specimens seem magnetically stable (Type II or Type III), the section is difficult to interpret with any confidence. These specimens were all demagnetized in peak A.F. fields of $200 \mathrm{Oe}$. Since this part of the section was sampled at $20-\mathrm{cm}$ intervals, a higher sampling density would probably provide a recognizable magnetostratigraphic pattern. Below about $50 \mathrm{~m}$ sub-bottom, that is, from Chron C-6 to basement (drilled on Anomaly 16), the section can be correlated with the GRTS with a high degree of confidence (see the dashed lines in Fig. 6). Specimens in this interval are highly stable and are Type I or Type II.

In Figure 7 we have plotted sediment accumulation versus age. There is a gradual increase in sedimentation rate with increasing depth; the rate increases from an average of $1.6 \mathrm{~m} / \mathrm{m} . \mathrm{y}$. at the Miocene/Oligocene boundary to an average of $9.2 \mathrm{~m} / \mathrm{m} . \mathrm{y}$. at the Oligocene/Eocene boundary and then decreases to $6.5 \mathrm{~m} / \mathrm{m}$.y. in the upper Eocene. The curve presented in Figure 7 can be differentiated to obtain the curve shown in Figure 8, where sediment accumulation rate is shown in units of $\mathrm{gm} / \mathrm{cm}^{2} / \mathrm{m} . \mathrm{y}$. versus age in m.y. The sharp increase (with decreasing age) to the Eocene/Oligocene boundary is followed by a general decay to the Oligocene/ Miocene boundary. There appears to be an oscillation in sediment accumulation rate within the Oligocene. The Miocene is characterized by low accumulation rates and is followed by a sharp rise to a peak in the middle Pliocene of $1200 \mathrm{gm} / \mathrm{cm}^{2} / \mathrm{m} . \mathrm{y}$. or $10.5 \mathrm{~m} / \mathrm{m}$.y. Since the Pliocene peak, there has been a gradual drop to the present rate of $525 \mathrm{gm} / \mathrm{cm}^{2} / \mathrm{m} . \mathrm{y}$. or $6.1 \mathrm{~m} / \mathrm{m}$.y.

Also plotted in Figure 8 are the $\mathrm{CaCO}_{3}$ and non$\mathrm{CaCO}_{3}$ accumulation rates. It is clear that the total accumulation rate is a strong function of $\mathrm{CaCO}_{3}$ dissolution and that the non- $\mathrm{CaCO}_{3}$ fraction remains relatively constant. A direct result of this is the variation in NRM intensity (Fig. 6), which decreases steadily with increasing $\mathrm{CaCO}_{3}$ accumulation rate. We believe this to be the result of the dilution of the relatively constant supply of magnetic material with nonmagnetic $\mathrm{CaCO}_{3}$ (see also Tucker and Tauxe, this vol.).

\section{Site 523}

The paleomagnetic results from Site 523 are presented in Figures 9 and 10. Above about $60 \mathrm{~m}$ sub-bottom, recovery was not continuous enough to allow the interpretation of a magnetostratigraphic section. All the specimens presented in Figure 9 were demagnetized in peak A.F. fields of $175 \mathrm{Oe}$ and are Type I or II. Our preferred correlation to the GRTS is shown in Figure 9 by dashed lines; the recovered sediments provide a record from Chron C-12 to near the bottom of Chron C-20. Site 523 was drilled on Anomaly 21, but equipment problems precluded the recovery of sediment all the way to basement (Chron C-21).

The decrease in NRM intensity with increasing depth starting at about $80 \mathrm{~m}$ sub-bottom is correlated with an 


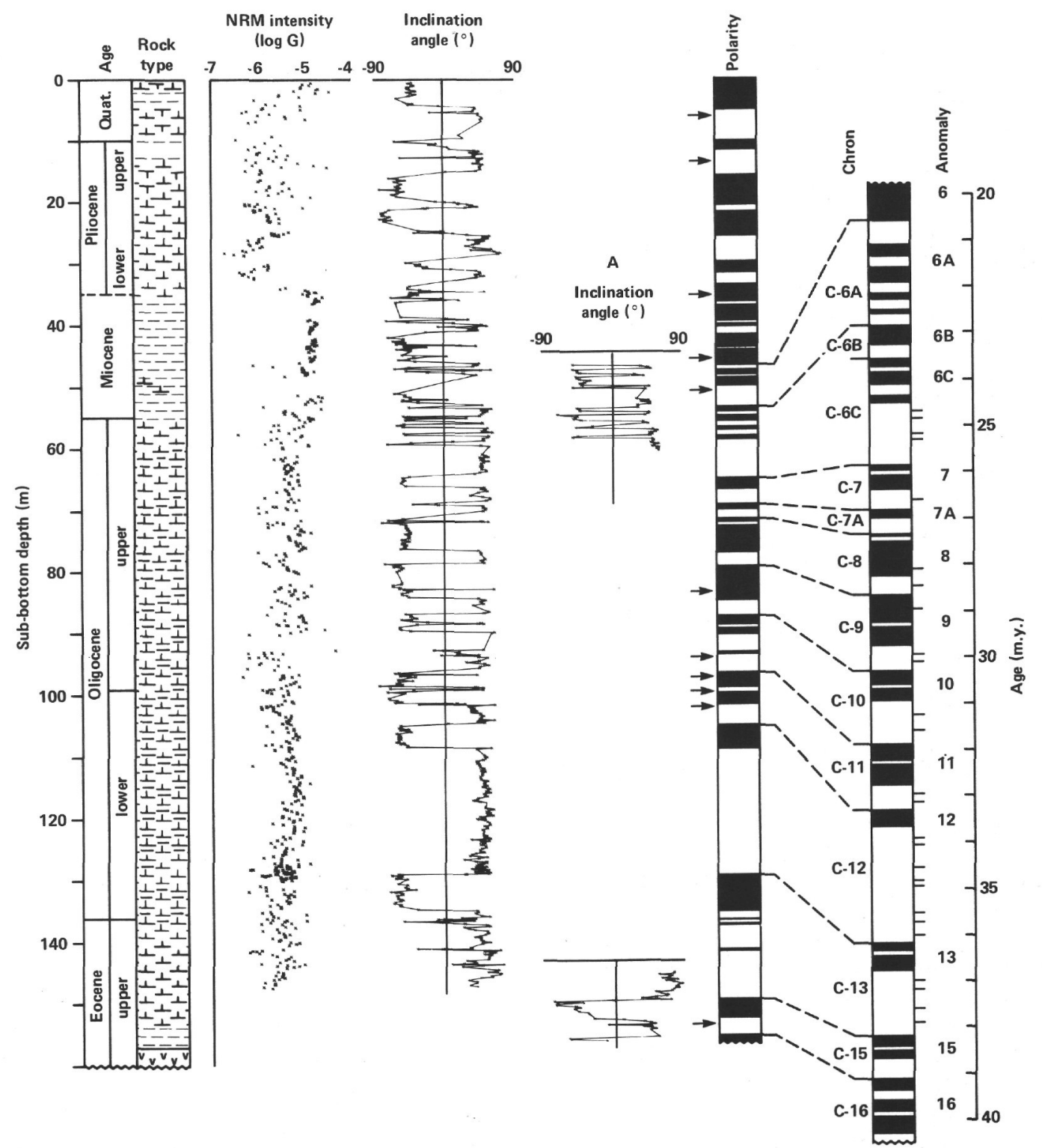

Figure 6. The magnetostratigraphy of Site 522 (see caption for Fig. 2). Column labeled A shows results from Hole $522 \mathrm{~A}$.

increase in sediment accumulation rate with increasing depth (see Fig. 10), as was observed at Site 522.

The results from Site 523 extend the Paleogene magnetostratigraphy well into the middle Eocene. The combined results of drilling at Sites 522 and 523 permit, for the first time, the direct comparison of the magnetostratigraphic and biostratigraphic time scales in deep sea sediment cores penetrating the Paleogene. The correlations are discussed elsewhere in this volume.

\section{Site 524}

The drilling at Site 524 differed from that at the other sites in that much of the section (below $40 \mathrm{~m}$ sub-bottom) was rotary cored. Recovery was excellent, the sediments were well lithified and magnetically stable (Type I or II), and the sampling interval was adequate (20-40 $\mathrm{cm})$; thus, the magnetostratigraphic pattern could be correlated to the GRTS with confidence from Chron
C-27 through Chron C-31 (Fig. 11). The presence of the Cretaceous/Tertiary boundary within Subchron C-29-R confirmed and complemented the results from the Gubbio section in Italy (Alvarez et al., 1977).

The presence of several short subchrons within the dominantly reversed Subchron C-26-R, which was first noted in the Gubbio section (Alvarez et al., 1977), was also noted at Site 524. The corroboration makes the existence of these subchrons more likely, even though there is little indication of short-term reversals in the magnetic anomaly profiles. Such subchrons would be helpful for correlation purposes, since they occur in a period characterized by a relatively slow reversal rate.

We are reasonably confidently of our correlation from Chron C-27-N to Chron C-25. The preferred correlation for the normal magnetic unit above Chron C-25 is based on biostratigraphic grounds and is discussed elsewhere in this volume. 


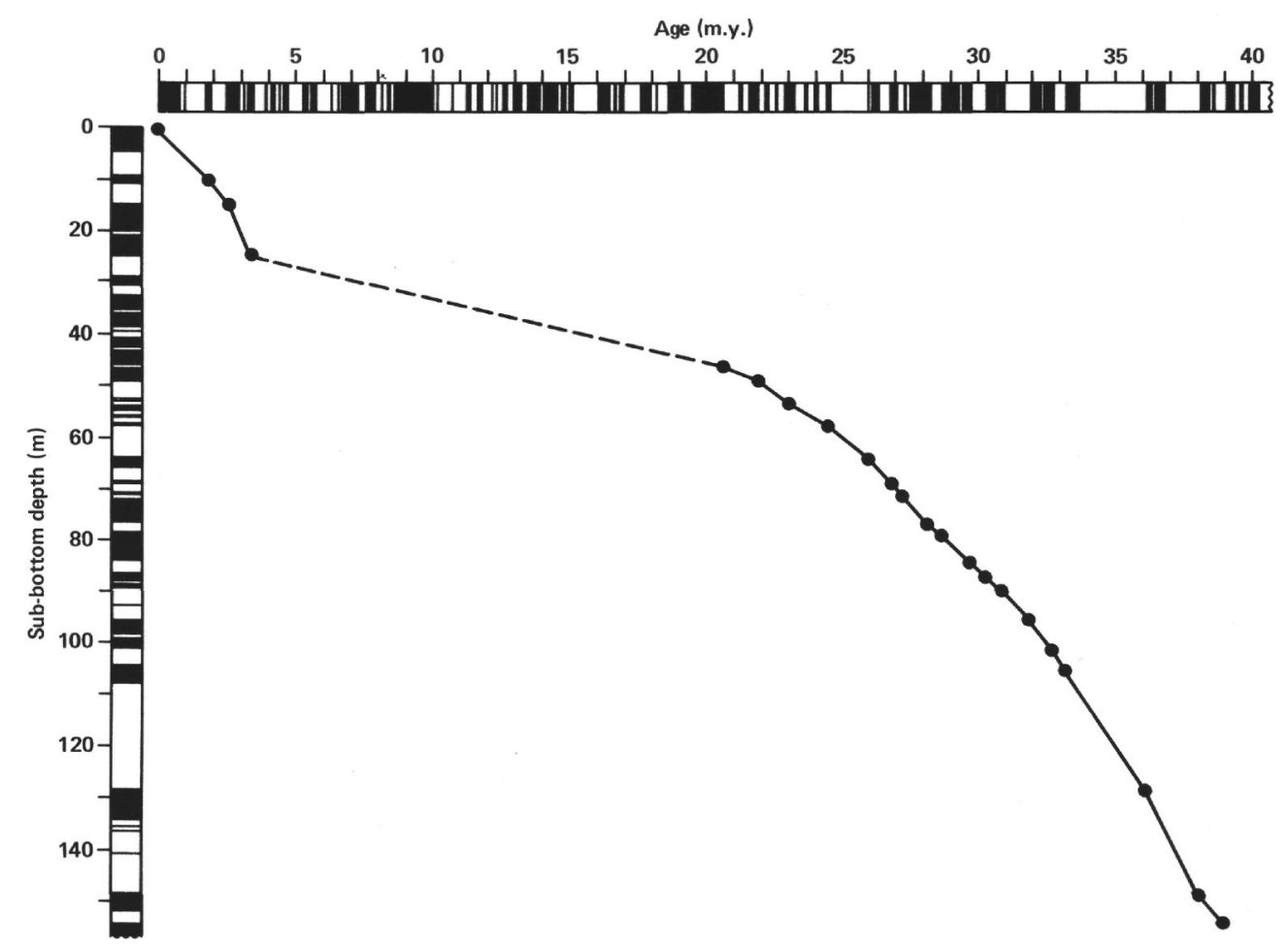

Figure 7. Sediment accumulation versus age at Site 522. Dashed line as in Fig. 5.

Figure 12 illustrates that an increase in sediment accumulation rate took place with increasing depth; from an average rate of $23.6 \mathrm{~m} / \mathrm{m}$.y. between Chrons C-25 and C-27 it increased to an average rate of $58.1 \mathrm{~m} / \mathrm{m} . \mathrm{y}$. The increase in rate is caused, not by the lack of dissolution that accompanies ridge crest facies, as at Sites 522 and 523 , but rather by an increase in the proportion of the non- $\mathrm{CaCO}_{3}$ component of the sediments in the form of volcanic detritus. This hypothesis is supported by the observation that NRM intensities increase with the increasing sediment accumulation rate at Site 524, the opposite of the trend noted for Sites 522 and 523.

\section{DISCUSSION}

\section{"Tiny Wiggles"}

Cande and LaBrecque (1974) and Blakely (1974) discussed the behavior of the Earth's magnetic field as deduced from small-scale marine magnetic anomalies. These "tiny wiggles" can be modeled equally well by fluctuations in the intensity of the dipole field and by short-period (less than 40,000-yr.) reversals of the magnetic field. In their time scale, LaBrecque et al. (1977) indicated the ambiguity in interpretation by noting the position of small but correlatable magnetic anomalies by tick marks or arrows at the side of the time scale.

We now have an independent set of data that places further constraints on the models of these marine magnetic anomalies. We sampled the period between Anomalies 12 and 13 (Subchron C-12-R) at an average rate of 1 specimen per 20,000 yr. and detected no additional subchrons. Site 523, which was sampled at a lower density, also failed to reveal additional reversals. If short- period reversals are the cause of the small-scale marine magnetic anomalies in Subchron C-12-R, then, they must be shorter than about 20,000 yr. in duration. However, if all eight "tiny wiggles" are caused by reversals it seems unlikely that we would not have found one in the 113 specimens from Site 522 or the 60 from Site 523.

In other intervals, however, the small-scale magnetic anomalies seem to correspond to short subchrons. The best documented of these are in Subchrons C-10-R and C-13-R at Site 522 (see Fig. 6). In addition to these, as already noted, there is a single reversed specimen in the magnetic unit correlated to Chron 9 at Site 519 (see Fig. 2) that may represent a short subchron.

These observations seem to indicate that at least some of the "tiny wiggles" record short-term subchrons. To be consistent with the data presented in this paper, these as yet undectected polarity reversals must be less than about 20,000 yr. in duration.

\section{Paleolatitudes}

There are problems connected with determining paleolatitudes from the paleomagnetic characteristics of DSDP drill cores. Pierce (1976) listed those that follow: (1) the need to assume that the cores were drilled vertically, (2) the possibility of undetected core disturbance, (3) the limited availability of sediment, (4) the statistical problems connected with calculating the averages of vectors where only the vertical component is known, and (5) the statistical problems connected with having to estimate how well the data have averaged out secular variation. We would add to this list the problems due to the effects of secondary overprinting, the effects of compaction, and the possibility of error in estimating 


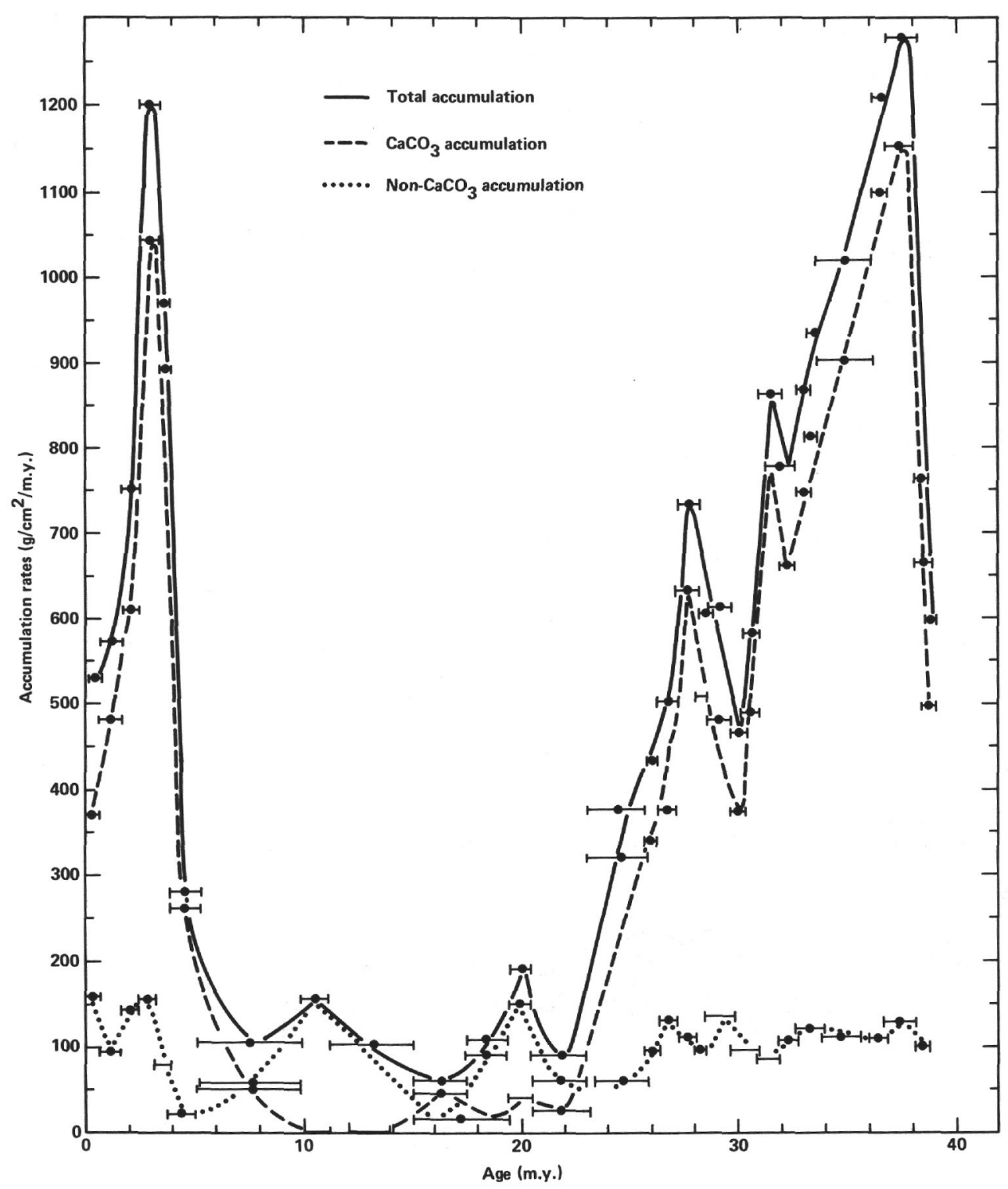

Figure 8. Accumulation rate curves at Site 522.

the depositional inclinations of nonbioturbated sediments.

The validity of assuming that the cores were drilled vertically was well substantiated on Leg 73: measured deviations from the vertical never exceeded $2^{\circ}$. The use of the HPC allowed the recovery of sediments with clear sedimentary features, and disturbed cores were not sampled, eliminating the second problem. Over the length of a hydraulic piston core there is relative declination control so that Fisher's (1953) statistics can be used to calculate true mean inclinations. However, at typical sediment accumulation rates, most cores span less than $1 \mathrm{~m} . y$. , potentially leading to the fifth problem. In order to obtain average inclinations over longer periods of time with the intent of averaging out secular variation, it is necessary to estimate the difference between the arithmetic mean and the true vector mean of a population of measurements where relative declinations are unknown. The arithmetic mean of paleomagnetic inclinations al- ways underestimates the true mean, and the error is a function of the dispersion of the population (large dispersion results in a large error) and the average inclination (the steepest inclinations have the largest error).

We employed the technique developed by Briden and Ward (1966) and refined by Kono (1980) to estimate true mean inclinations from the core data. If the population is assumed to have a Fisherian distribution (which is also required for Fisher's [1953] statistics), the true mean can be estimated if the arithmetic mean and the standard deviation along one axis (here the vertical axis) are known. If Kono's (1980) analysis is used, it is possible to compute a true mean and Fisherian precision parameter by iteration. Coupled with our precise age information, this technique allows us to estimate Fisher means and confidence limits over any given time interval.

In order to establish the accuracy of the Kono (1980) technique, Fisher mean inclinations and confidence 


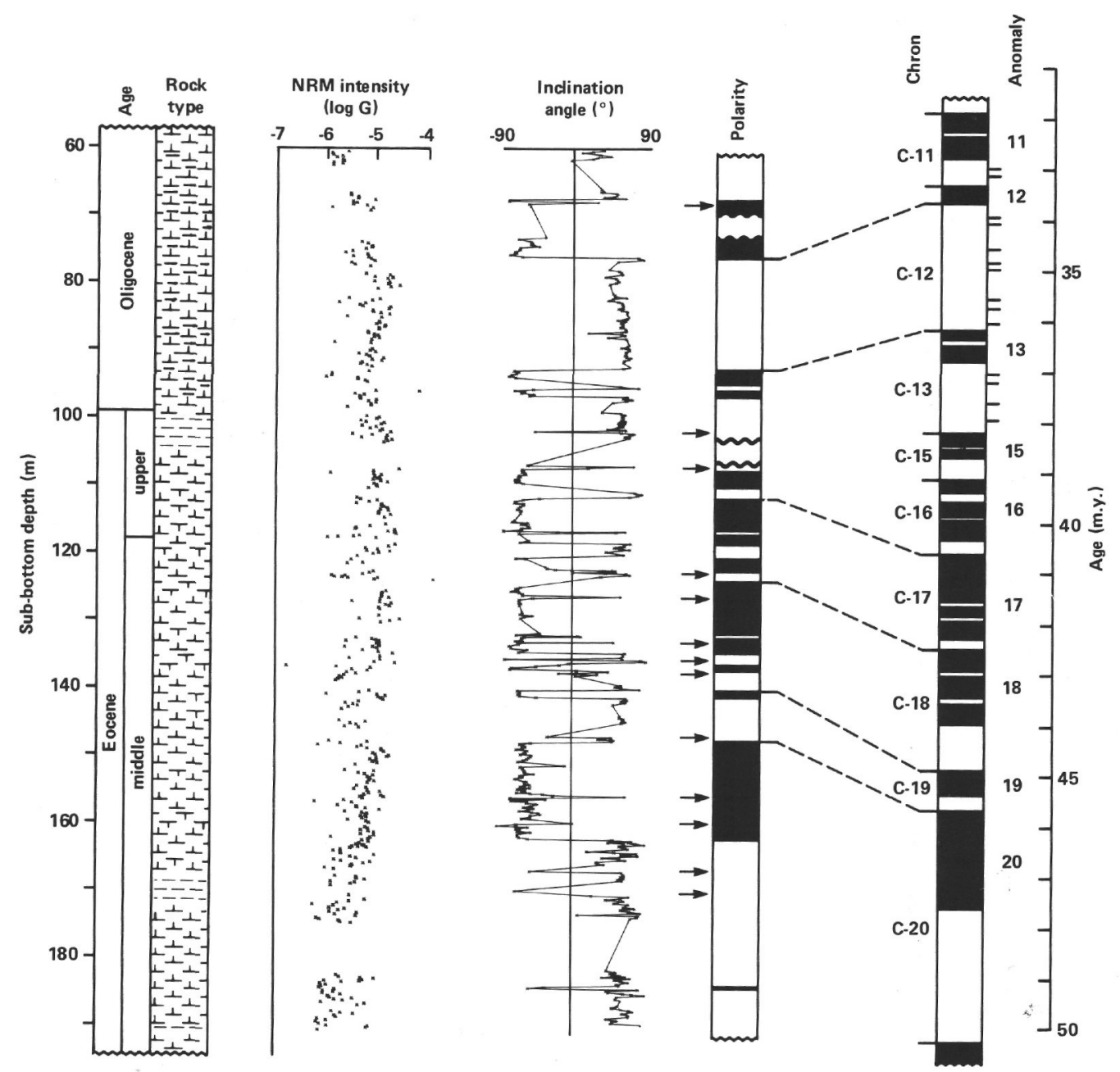

Figure 9. The magnetostratigraphy of Site 523 (see caption for Fig. 2).

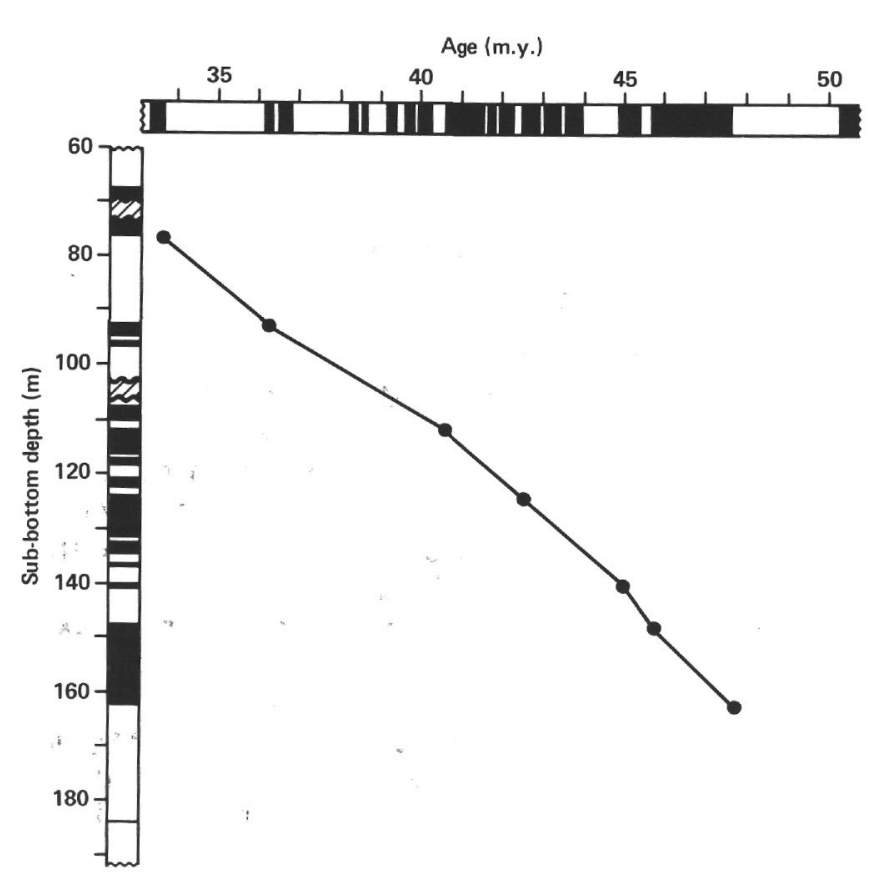

Figure 10. Sediment accumulation versus age for Site 523. limits were calculated for Site 519 whole cores and compared with those estimated by using the Kono (1980) technique. The high precision of 0.7160 for all cores and 0.9896 for estimated precision coefficients of greater than 20 suggests that our estimates are accurate. The estimated confidence limits $\left(\alpha_{95}\right)$ are slightly narrower than those calculated by using standard Fisher (1953) statistics. However, relative $\alpha_{95}$ estimates are accurate at the $99 \%$ level of confidence. Since the same assumption (that the population is Fisherian) goes into using both standard Fisher (1953) statistics and the approximations of Briden and Ward (1966), the Briden and Ward (1966) estimates may be more accurate for core data than standard Fisher (1953) techniques, because declinations can easily be artificially spread, thereby violating the assumption underlying a Fisher distribution.

The additional problems of the effects of secondary overprinting, compaction, and depositional inclination error have also been considered. The present field inclination is steeper at every site than the inclination expected from an axial geocentric dipole. Therefore a viscous overprint acquired in the present field will result in steeper normal inclinations and shallower reversed inclinations, characteristics that make the overprint readi- 


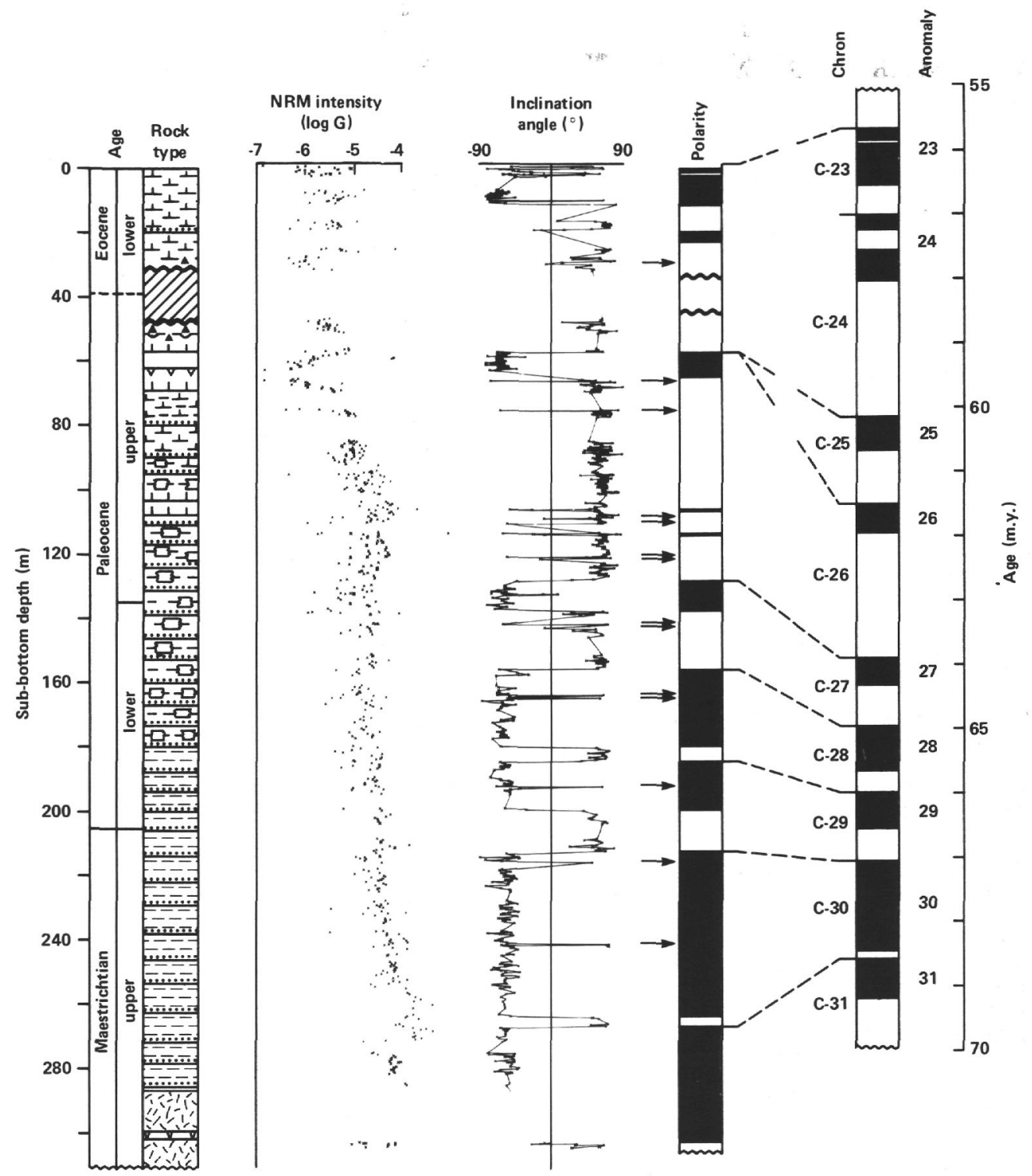

Figure 11. The magnetostratigraphy of Site 524 (see caption for Fig. 2).

ly detectable. Both compaction and depositional inclination error act to produce shallower inclinations in both normal and reversed populations. The effect of compaction is suggested by a tendency toward downhole shallowing. A depositional inclination error is suspected when the sediments are slump or turbidite deposits. The effect of a persistent slight secondary overprint is shown for Site 522 in Figure 13A and by the consistent separation of the averages of normal and reversed inclinations. This effect is not observed at Site 523 or 524 (Figs. 13B and C). The effect at Site 522 is considered slight and has not greatly affected the calculation of paleolatitudes to follow.

A tendency toward downhole shallowing is suggested at Sites 523 and 524 (Figs. 13B and 13C). For this reason, paleolatitudes calculated from sediments deeper than about $100 \mathrm{~m}$ should be considered minimum estimates.

By using estimated average inclinations over 10-m.y. periods, we have calculated paleolatitudes for Sites 522,
523, and 524 (see Fig. 14 and Table 2). The general trend is for the continuous northward motion of the African plate throughout the Cenozoic. The implications for the apparent polar wander path of Africa are discussed by Tauxe et al. (1983).

\section{SUMMARY AND CONCLUSIONS}

1. The data presented in this paper provide the basis for the magnetic stratigraphy of five drill sites in the South Atlantic. Drilling at three of these penetrated $\mathrm{Pa}$ leogene sediments, creating the first opportunity for a direct correlation between Paleogene magnetostratigraphic and biostratigraphic time scales.

2 . In addition to permitting correlations with biostratigraphic data, the magnetostratigraphy allows sediment accumulation rates to be determined for each site.

3. The data presented here have a bearing on the problem of "tiny wiggles." At least some of the smallscale marine magnetic anomalies could be the result of 


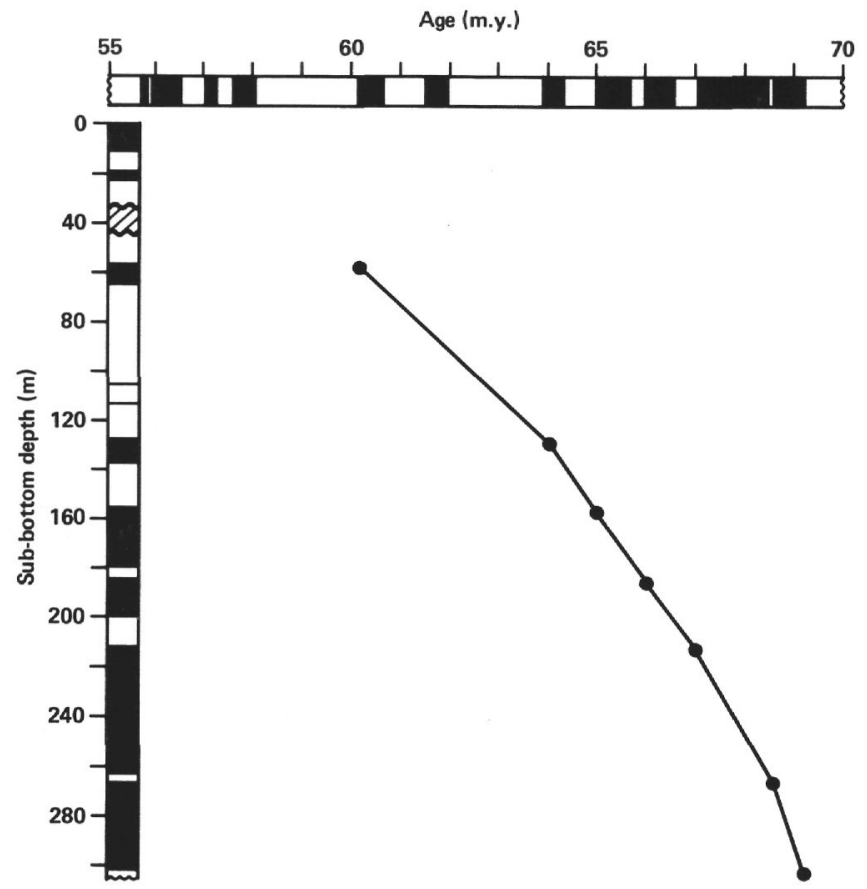

Figure 12. Sediment accumulation versus age for Site 524.

Table 2. Paleolatitudes of Sites 522, 523, and 524 calculated from $10-m . y$. inclination averages.

\begin{tabular}{ccccc}
\hline Site & $\begin{array}{c}\text { Age interval } \\
(\mathrm{m} . \mathrm{y} .)\end{array}$ & $\begin{array}{c}\text { Number of } \\
\text { specimens }\end{array}$ & $\begin{array}{c}\text { Paleolatitude } \\
\left({ }^{\circ} \mathrm{S}\right)\end{array}$ & $\begin{array}{c}\mathrm{dp}^{\mathrm{a}} \\
\left({ }^{\circ}\right)\end{array}$ \\
\hline 522 & $20-30$ & 155 & 32.3 & 1.5 \\
523 & $30-40$ & 298 & 31.7 & 1.5 \\
& $30-40$ & 147 & 40.0 & 3.1 \\
524 & $40-50$ & 246 & 41.2 & 2.3 \\
\hline
\end{tabular}

a $95 \%$ confidence interval of paleolatitude.

short-period reversals of the magnetic field (notably those between Anomalies 10 and 11 and between Anomalies 13 and 15). Our data further constrain any as yet undetected subchrons to be shorter than about $20,000 \mathrm{yr}$.

4. Using the technique of Briden and Ward (1966) and Kono (1980), we calculated paleolatitudes for the sites versus time from average inclinations. These calculations provide constraints for paleoceanographic models of the South Atlantic as well as for the apparent polar wander path of Africa.

\section{REFERENCES}

Alvarez, W., Arthur, M. S., Fischer, A. F., Lowrie, W., Napoleone, G., Premoli Silva, I., and Roggenthern, W. M., 1977. Type section for the Late Cretaceous-Paleocene reversal time scale. Geol. Soc. Am. Bull., 88:367-389.

Barndt, J., Johnson, N. D., Lindsay, E. H., Pilbeam, D., and Tahirkheli, R. A. K., 1978. The magnetic polarity stratigraphy and age of the Siwalik Group near Dhok Pathan Village, Potwar Plateau, Pakistan. Earth Planet. Sci. Lett., 41:355-364.

Blakely, R. J., 1974. Geomagnetic reversals and crustal spreading rates during the Miocene. J. Geophys. Res. 79:279-300.

Briden, J. C., and Ward, M. A., 1966. Analysis of magnetic inclinations in bore cores. Pure Appl. Geophys., 63:133-152.
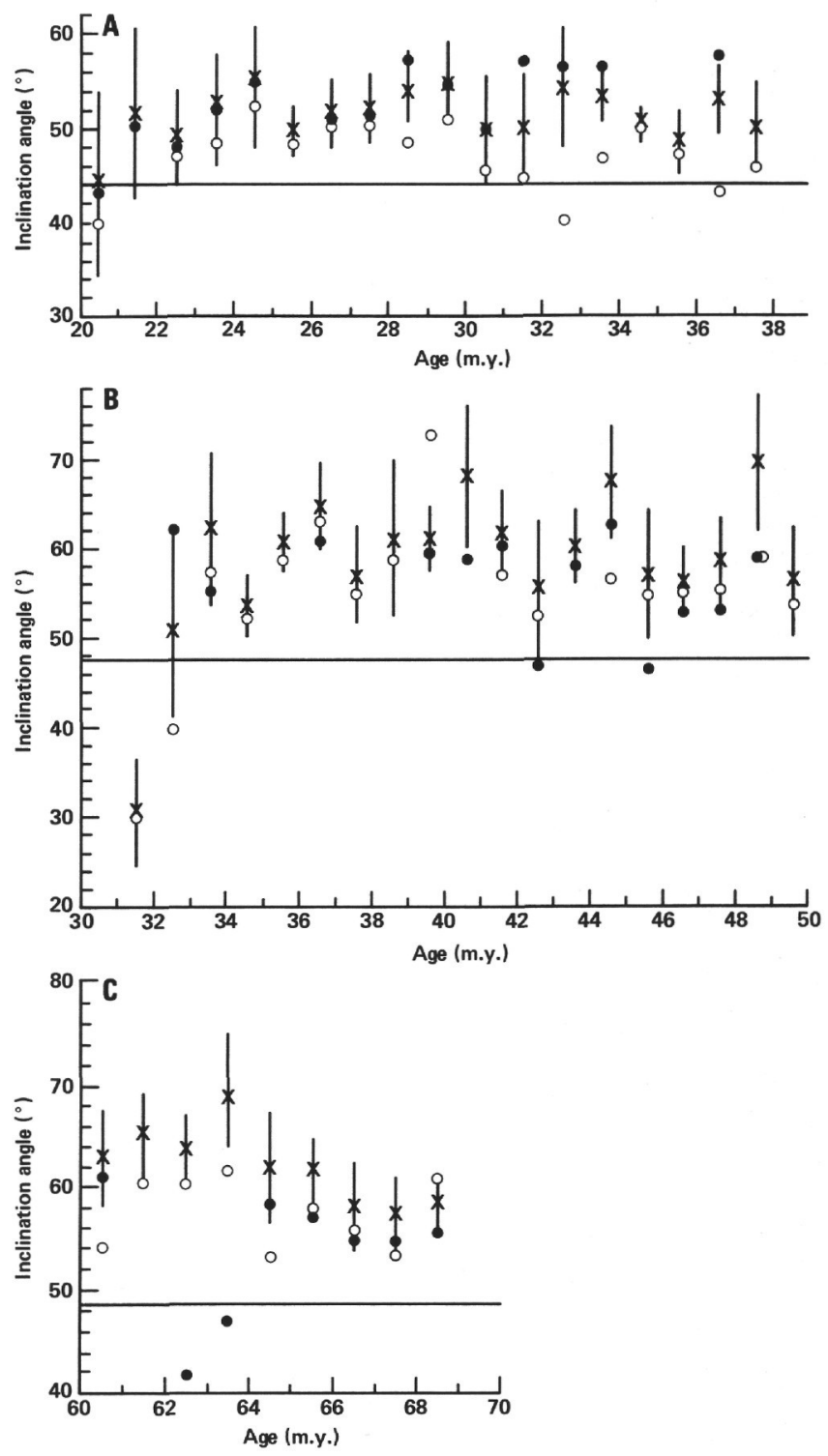

Figure 13. One-m.y. averages of inclinations for paleomagnetic data. Crosses are averages estimated by using the techniques described in the text. Black dots are the averages of normal (negative) inclinations. White dots are the averages of reversed (positive) inclinations. Error bars represent the estimated circles of confidence at the $95 \%$ level of certainty. A. Site 522. B. Site 523. C. Site 524.

Butler, R. F., and Coney, P. J., 1981. A revised time scale for the Paleocene and early Eocene and implications for Pacific plate motion. Geophys. Res. Lett., 8:301-304.

Cande, S. C., and LaBrecque, J. L., 1974. Behavior of the Earth's paleomagnetic field from small scale marine magnetic anomalies. Nature, 247:26-28.

Cox, A., Doell, R. R., and Dalrymple, G. B., 1963. Geomagnetic polarity epochs and Pleistocene geochronometry. Nature, 198: 1049-1051.

1964. Reversals of the Earth's magnetic field. Science, 144: $1537-1543$.

Fisher, R. A., 1953. Dispersion on a sphere. Philos. Trans. R. Soc. London Ser. A, 217:295-305.

Hailwood, E. A., Bock, W., Costa, L., Dupeuble, P. A., Müller, C., and Schnitker, D., 1979. Chronology and biostratigraphy of Northeast Atlantic sediments, DSDP Leg 48. In Montadert, L., 
Roberts, D. G., et al., Init. Repts. DSDP, 48: Washington (U.S. Govt. Printing Office), 1119-1141.

Hardenbol, J., and Berggren, W. A., 1978. A new Paleogene numerical time scale. In Cohee, G. V., Glaessner, M. F., and Hedberg, H. D. (Eds.), Contributions to the Geologic Time Scale, Stud. Geol. Tulsa Okla., 6:213-234.

Hays, J. D., and Opdyke, N. D., 1967. Antarctic radiolaria, magnetic reversals and climatic change. Science, 158:1001-1011.

Hays, J. D., Saito, T., Opdyke, N. D., and Burckle, L. H., 1969. Plio-Pleistocene sediments of the equatorial Pacific: their paleomagnetic, biostratigraphic and climatic record. Geol. Soc. Am. Bull., 80:1481-1514.

Hedberg, H. D., Salvador, A., and Opdyke, N. D., 1979. Magnetostratigraphic polarity units-a supplementary chapter of the ISSC International Stratigraphic Guide. Geology, 7:578-583.

Heirtzler, J. R., Dickson, G. O., Herron, E. M., Pitman, W. C., III, and LePichon, X., 1968. Marine magnetic anomalies, geomagnetic field reversals and motions of the ocean floor and continents. J. Geophys. Res., 73:2119-2136.

Kono, M., 1980. Statistics of paleomagnetic inclination data. $J$. Geophys. Res., 85:3878-3882.

LaBrecque, J. L., Kent, D. V., and Cande, S. C., 1977. Revised magnetic polarity time scale for Late Cretaceous and Cenozoic time. Geology, 5:330-335.

Lowrie, W., Alvarez, W., Napoleone, G., Perch-Nielson, K., Premoli Silva, I., and Toumarkine, M., 1982. Paleogene magnetic reversal stratigraphy in Umbrian pelagic carbonate rocks. Geol. Soc. Am. Bull., 93:414-432.

McDougall, I., Watkins, N. D., Walker, G., and Kristjarsson, L., 1976. K-Ar and paleomagnetic analysis of Icelandic lava flows: limits on the age of Anomaly 5. J. Geophys. Res., 81:1505-1512.

Mankinen, E. A., and Dalrymple, G. B., 1979. Revised geomagnetic polarity time scale for the interval 0-5 m.y.B.P. J. Geophys. Res., $84: 615-626$

Opdyke, N. D., Burckle, L. H., and Todd, A., 1974. The extension of the magnetic time scale in sediments of the Central Pacific Ocean. Earth Planet. Sci. Lett., 22:300-306.

Pierce, J. W., 1976. Assessing the reliability of DSDP paleolatitudes. J. Geophys. Res., 81:4173-4187.

Ryan, W. B. F., Cita, M. B., Dreyfus-Rawson, M., Burckle, L. H., and Saito, T., 1974. A paleomagnetic assignment of Neogene stage boundaries and the development of isochronous datum planes between the Mediterranean, the Pacific and Indian oceans in order to investigate the response of the world ocean to the Mediterranean "salinity crisis". Riv. Ital. Paleontol., 80:631-688.

Sclater, J. G., Jarrard, R. D., McGowran, B., and Gartner, S., Jr., 1974. Comparison of the magnetic and biostratigraphic time scales since the Late Cretaceous. In von der Borch, C. C., Sclater, J. G., et al., Init. Repts. DSDP, 22: Washington (U.S. Govt. Printing Office), 381-386.

Tauxe, L., 1979. A new date for Ramapithecus. Nature, 282:399-401.

Tauxe, L., Besse, J., and LaBrecque, J. L., 1983. Paleolatitudes from DSDP Leg 73 sediment cores: implications for the APWP for
Africa during the Mesozoic and Cenozoic. Geophys. J. R. Astron. Soc., 73:315-324.

Tauxe, L., and Opdyke, N. D., 1982. A time framework based on magnetostratigraphy for the Siwalik sediments of the Khaur area, Northern Pakistan. Palaeogeogr. Palaeoclimatol. Palaeoecol., 37 43-61.

Theyer, F., and Hammond, S. R., 1974. Paleomagnetic polarity sequence and radiolarian zones, Brunhes to polarity Epoch 20. Earth Planet. Sci. Lett., 22:307-319.

Date of Initial Receipt: March 29, 1982

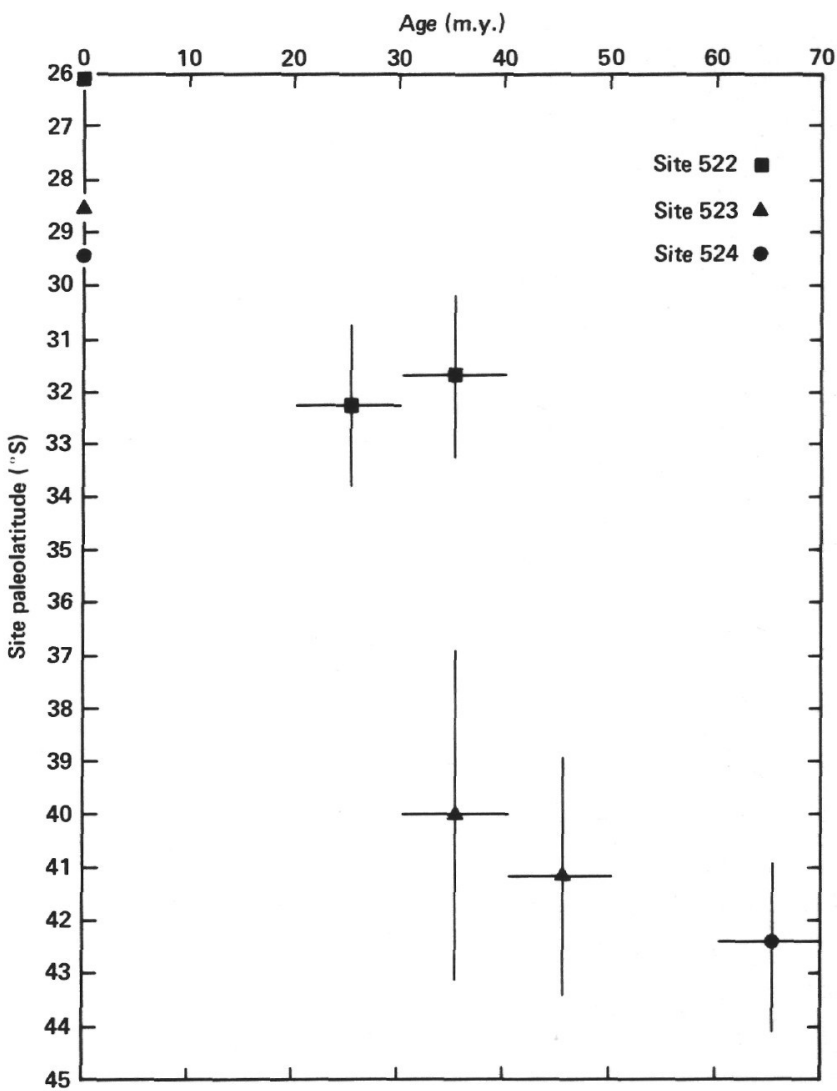

Figure 14. Site paleolatitudes versus time for Sites 522, 523, and 524 . Paleolatitudes are calculated from 10-m.y. averages of inclinations using the techniques described in the text. 